\title{
Establishing reproductive potential and advances in fertility preservation techniques for XY individuals with DSD (differences in sex development)
}

\section{Running title: Fertility preservation for individuals with DSD}

Rumana Islam ${ }^{1}$, Sheila Lane ${ }^{2}$, Suzannah A. Williams ${ }^{3}$, Christian M. Becker ${ }^{4}$, Gerard S. Conway5, Sarah M. Creighton ${ }^{6}$

${ }^{1}$ Department of Reproductive Medicine, John Radcliffe Hospital, Oxford University Hospitals,

2Department of Paediatric Oncology and Haematology, John Radcliffe Hospital, Oxford University Hospitals

${ }^{3}$ Nuffield Department of Women's and Reproductive Health, University of Oxford, Women's Centre, John Radcliffe Hospital

${ }^{4}$ Oxford Endometriosis CaRe Centre, Nuffield Department of Women's and Reproductive Health, University of Oxford, Women's Centre, John Radcliffe Hospital,

${ }^{5}$ Department of Endocrinology, University College London Hospitals, 250 Euston Road, London, NW12PG

${ }^{6}$ Elizabeth Garrett Anderson UCL Institute of Women's Health, University College London Hospitals, 250 Euston Road, London, NW12PG

*Corresponding author

\section{Conflict of Interest}

None to declare

\section{Summary}

Discordance between gonadal type and gender identity has often led to an assumption of infertility in patients with differences in sex development (DSD). However, there is now greater recognition of fertility being an important issue for this group of patients. Currently, gonadal tissue that may have fertility potential is not being stored for individuals with DSD and, where gonadectomy forms part of management, is often discarded. 
The area of fertility preservation has been predominantly driven by oncofertility which is a field dedicated to preserving the fertility of patients undergoing gonadotoxic cancer treatment. The use of fertility preservation techniques could be expanded to include individuals with DSD where functioning gonads are present.

\section{Methods}

This is a systematic literature review evaluating original research articles and relevant reviews between 1974-2018 addressing DSD and fertility, in vitro maturation of sperm, and histological/ultrastructural assessment of gonadal tissue in complete and partial androgen insensitivity syndrome, 17 $\beta$ hydroxysteroid dehydrogenase type 3 and $5 \alpha$-reductase deficiency.

\section{Conclusion}

Successful clinical outcomes of ovarian tissue cryopreservation are paving the way for similar research being conducted using testicular tissue and sperm. There have been promising results from both animal and human studies leading to cryopreservation of testicular tissue now being offered to boys prior to cancer treatment. Although data are limited, there is evidence to suggest the presence of reproductive potential in the gonads of some individuals with DSD. Larger, more detailed studies are required, but if these continue to be encouraging, individuals with DSD should be given the same information, opportunities and access to fertility preservation as other patient groups.

Keywords: differences in sex development; fertility preservation; in vitro maturation, testicular tissue cryopreservation; spermatogonial cells; androgen insensitivity syndrome, androgen synthesis defects. 


\section{Establishing reproductive potential and advances in fertility preservation techniques for XY individuals with DSD (differences in sex development)}

\section{Background:}

Differences (sometimes referred to as disorders) of sex development (DSD) are characterised by discordance between an individual's phenotype, gonadal status and karyotype. Incongruity between gonadal type and gender identity has historically led to an assumption of infertility. Fertility is often affected by DSD due to gonadal and endocrine disturbances, or direct anatomical reasons inherent to the DSD. Recently there has been a greater recognition that fertility is an important aspect of care for this group of patients. The 2016 update of the International Consensus Conference on intersex disorders addressed polarizing topics, which included reference to the importance of fertility, but with recognition that evidence about the best fertility preserving options remains inadequate ${ }^{1,2}$.

Fertility preservation technologies (storage of oocytes, sperm, or precursor reproductive tissue for future use) and societal perceptions towards nontraditional family structures have expanded significantly in recent years, such that having a biological child is now possible for a significant proportion of adults with DSD. Although technology is still evolving, promising research using animal models leads to an expectation that primordial oocytes and sperm cells will soon be able to be matured in vitro and used with assisted reproductive technologies to produce a biological child.

The purpose of this article is to provide an overview of preservation of biological fertility potential for XY individuals with DSD who undergo gonadectomy either because of an increased risk of gonadal malignancy or as part of female gender reassignment. This is a systematic literature review evaluating original research articles and relevant reviews between 1974-2018 regarding DSD and fertility, in vitro maturation of sperm, and histological/ultrastructural assessment of 
gonadal tissue in complete and partial androgen insensitivity syndrome, $17 \beta$ hydroxysteroid dehydrogenase type 3 and $5 \alpha$-reductase deficiency.

\section{Conditions}

Spermatogenesis is initiated by genes located on the long arm of the $Y$ chromosome ${ }^{3}$ and completed under the influence of pituitary gonadotropins ${ }^{4}$. Diploid A pale spermatogonia generally undergo mitotic division to constantly regenerate forming another $\mathrm{A}$ pale and a B spermatogonia. The latter pass through the blood testis barrier and develop into primary spermatocytes. The first meiotic division of primary spermatocytes produces two haploid secondary spermatocytes, which then undergo a second meiotic division to produce four spermatids. The resulting spermatids mature into spermatozoa within the testis ${ }^{5,6}$. Sperm maturation is facilitated by the action of pituitary gonadotropins, stimulating Leydig cell production of testosterone and Sertoli cell production of androgen-binding protein to transport the testosterone through the blood testis barrier? ${ }^{7}$ Disruption by certain conditions of this pathway leads to infertility.

\section{Complete androgen insensitivity syndrome}

Complete androgen insensitivity syndrome (CAIS) is an X-linked difference of sex development (DSD) where affected individuals have an XY karyotype and intrabdominal/inguinal testes but are phenotypically female with normally developed female external genitalia ${ }^{8}$. The condition is caused by inactivating mutations of the androgen receptor (AR) gene, rendering ARs insensitive to androgen stimulation ${ }^{9}$. The normal-functioning testes produce androgens as well as anti-müllerian hormone (AMH) which inhibits formation of the uterus in utero. Individuals with CAIS typically present with primary amenorrhoea but earlier diagnoses can be made if prenatal genetic testing is inconsistent with postnatal phenotype or if an inguinal hernia in a female child is found to contain a testis. Pubic and axillary hair growth is sparse in these patients but breast development occurs at the expected time of puberty due to increased levels of oestrogen from aromatization of excessive androgen substrate from the testes ${ }^{10}$. 
The risk of gonadal tumour development in CAIS patients is thought to increase with age with incidence rates ranging from $0.8-16 \% 1112,13$ in patients who retained their testes into adulthood and up to $30 \%$ if retained into late adulthood 14,12. However, there are no prospective long-term trials on cancer risk as gonadectomy was almost universally performed until relatively recently 15 . Invasive germ cell tumours such as seminomas/non-seminoma and dysgerminomas/non-dysgerminoma are usually preceded by a non-invasive 'germ cell neoplasia in situ' (GCNIS) phase 16. At present, there is no validated screening for GCNIS since research into magnetic resonance imaging (MRI) and biomarkers in predicting malignancy risk is inconclusive ${ }^{17,18}$. Therefore, current best practice is to recommend a gonadectomy in adolescence after completion of spontaneous puberty, as the risk of malignancy is low prior to puberty ${ }^{11}$.

Testicular histology in CAIS has shown incomplete spermatogenesis, decreased percentage of type A dark spermatogonia, increased fibrosis, hyperplastic Leydig cells ${ }^{14}$ and Sertoli nodules ${ }^{19}$. Studies found the majority of patients have testes containing spermatogonia with occasional spermatocytes ${ }^{20}$. These were observed to be the most abundant in the first year of life, with normal numbers, followed by progressive loss 20,21 .

\section{Partial androgen insensitivity syndrome}

Unlike CAIS, the decision about whether to raise the child as male or female in partial androgen insensitivity syndrome (PAIS) is not straightforward. The clinical presentation depends on the degree of responsiveness of the external genitalia to androgens. The typical phenotype is a micropenis, severe hypospadias (perineoscrotal), and a bifid scrotum that might contain gonads. Some centres report an increasing trend over recent decades to choose rearing the child as male in PAIS ${ }^{22}$. Androgen supplementation might be needed at puberty in patients with androgen resistance but is not always necessary. Surgery is usually performed during the second to third year of life to repair hypospadias and bring undescended testes into the scrotum.

If the child is raised as female then the management is similar to that of CAIS. 
The risk of germ-cell tumours is higher in partial than in complete androgen insensitivity syndrome, with a suggested incidence of $15 \%{ }^{12}$. Therefore, PAIS patients reared as female typically undergo gonadectomy at time of diagnosis, while patients reared male undergo external genital reconstruction and orchiopexy for possible fertility preservation, with close monitoring and regular testicular self-examination.

Males with mild androgen insensitivity syndrome have oligo or azoospermia and are subfertile but there is one reported case of spontaneous pregnancy ${ }^{23}$.

\section{Androgen synthesis disorders}

Androgen synthesis defects, such as $17 \beta$-hydroxysteroid dehydrogenase type 3 and $5 \alpha$-reductase deficiency (5ARD), result in varying degrees of undermasculinization depending on the enzyme deficiency. Individuals with these deficiencies have often been brought up as female, but if testes are retained they experience variable virilization during puberty ${ }^{24-26}$. Affected individuals may be infertile due to the lack of spermatogenesis. However, fertility is likely in those with milder phenotypes.

\section{5 alpha-reductase deficiency}

5ARD results from impaired conversion of testosterone to dihydrotestosterone $(\mathrm{DHT})^{27}$. Mutation of the SRD5A2 gene leads to an autosomal recessive disorder affecting sexual differentiation in individuals with $46 \mathrm{XY}$ karyotype; their phenotype ranging from almost normal female structures to a distinct male phenotype when older with ambiguous genitalia at birth ${ }^{28}$. Given the severe defect of the external genitalia, most newborns are raised as females ${ }^{29}$. Patients exhibit virilization at puberty without breast development, which can be accompanied by a gender identity change from female to male 30 .

In most instances, the testes are located in the inguinal region. Testicular descent through the inguinal canal is generally arrested in 46XY individuals with 5ARD. Semen abnormalities in this situation include oligozoospermia with reduced volume and high viscosity. One histological study reported that patients lacked spermatocytes but had Ad spermatogonia and a normal germ cell count, 
compared to those with isolated cryptorchidism appearing to have a decreased number of germ cells but evidence of primary spermatocytes. This suggests that DHT plays a role in proliferation and differentiation of spermatocytes ${ }^{31}$. Other studies, performing ultrastructural analysis, have demonstrated that spermatogenesis is universally impaired 32,33 .

It has also been suggested that subfertility in men with 5ARD may be a consequence of an intrinsic failure of the Sertoli cell to reach a fully functional state at puberty ${ }^{34}$.

While spontaneous paternity in men with 5ARD is extremely rare due to azoospermia or oligoasthenoteratozoospermia, following bilateral orchidopexy and male genital reconstruction, there are case reports of successful pregnancies and live births using intrauterine insemination and IVF with ICSI 35, 36. The increasing efficacy of these techniques, including testicular sperm extraction (TESE) and cryopreservation of testicular tissue in cases of azoospermia, makes biological parenthood a future possibility for the most severely affected men with this enzyme defect.

\section{7-beta hydroxysteroid dehydrogenase 3 deficiency}

17-beta hydroxysteroid dehydrogenase 3 (17ßHSD-3) is primarily expressed in the testes and converts androstenedione to testosterone, which is necessary for normal masculinization of external genitalia in utero. The condition is autosomal recessive with mutations in HSD17B3 ${ }^{37}$. The majority of affected individuals are born with female or with ambiguous external genitalia. While some individuals may be diagnosed in infancy after evaluation for ambiguous genitalia or inguinal hernia, many are not diagnosed until puberty, when they present with virilization. Virilization at puberty may be due to residual activity of $17 \beta$ HSD-3 in the presence of increased androstenedione, as well as activity of extragonadal $17 \beta$ HSD isoenzymes ${ }^{38}$. Gender reassignment from female to male has been reported in $39-64 \%$ in patients who were initially raised as girls ${ }^{30}$.

For patients raised male with retention of testes, spontaneous fertility is unlikely. While there is a single reported case of a patient (with a history of 
genital reconstruction in adolescence) having fathered a child ${ }^{39}$ examination of testicular histology in these patients reveals arrested spermatogenesis ${ }^{40}$ which is inconsistent with reproductive capacity ${ }^{41}$. Studies of gonadal tissue removed from young pre-pubertal patients demonstrate Leydig and Sertoli cell hyperplasia ${ }^{42,43}$. Although the seminiferous tubules are filled mostly by Sertoli cells, clusters of spermatogonia and spermatocytes are located at intervals along their lengths ${ }^{44}, 45$. However spermatogonia are absent or very immature by the time of puberty 39,46 .

It is unknown whether early orchidopexy would result in a more favourable outcome. An intermediate risk (28\%) of germ cell malignancy has been cited in those who do not undergo orchidectomy: However, this risk is based on a small sample size ${ }^{47}$

\section{Preservation of biological fertility potential:}

Fertility is often affected by DSD due to gonadal and endocrine disturbances, or direct anatomical reasons inherent to the DSD. In the conditions discussed above, it is likely that both exposure of the cryptorchid testis to abnormally high temperatures ${ }^{31}$, and mutations associated with impaired gene expression affecting SSC differentiation and development, induce germ cell loss and infertility ${ }^{48,49}$. There is little datum regarding the fertility potential of the testes in XY DSD including those that are removed due to increased risk of malignancy or if the child is to be reared as female. Earlier studies evaluated the presence of germs cells in selected populations, mainly CAIS and 5ARD $17,50,51$.

However, a recent pilot study evaluated the presence of germs cells in the gonads of individuals with a broad range of DSDs as a possible indicator of fertility potential ${ }^{52}$ and the relationship between age and the presence of germ cells in this population. This study did not distinguish between spermatogonia and more mature spermatogenic cells.

Forty-four patients with DSD aged 0 to 18 years old who underwent gonadectomy or biopsy and 42 aged matched control gonads were obtained from 
patients who underwent gonadectomy for benign conditions and from autopsy specimens. Germ cell morphology and cell counts were derived from hematoxylin and eosin stained sections and the average number of germ cells per $\mathrm{mm}^{2}$ were calculated. Germ cell density, by condition, is described below. These data revealed fertility potential by the presence of germ cells in all patients with CAIS, mixed gonadal dysgenesis (MGD) and ovotesticular DSD included in the study.

All 6 patients with CAIS had germ cells present in their testicular tissue $(62 \pm$ 111) (mean \pm SD number of germ cells $/ \mathrm{mm}^{2}$ ). In CAIS gonads Sertoli cell nodules and areas of hyperplasia contained no germ cells but all 6 of these patients had germ cells present in areas between nodules.

All 6 patients with mixed gonadal dysgenesis (ovary $19 \pm 14(10-35)$, testis $22 \pm$ 21 (2-43) and both participants with ovotesticular DSD had germs cells present in their gonadal tissue (ovary, $190 \pm 57$ (21-230), testis $62 \pm 54$ (23-100) and ten of the twelve with DSD not otherwise specified had germ cells in the gondal tissue. The average number of ovarian and testicular germ cells per $\mathrm{mm}^{2}$ in patients with DSD showed a strong inverse correlation with age (percentage of participants with germ cells present per age group: 0-3 years 88\%, 4-11 years $50 \%$ and $12-18$ years $42 \%$ ). This is important to consider as delaying gonadectomy in some conditions, such as CAIS, may actually decrease fertility potential.

Germ cells were not found in any of the patients with complete gonadal or partial gonadal dysgenesis. These few studies represent the only available human evidence of fertility potential in DSD patients but suggest presence of germ cells in all patients with CAIS, MGD and ovotesticular 17, 50, 51,

The largest follow-up study to date to investigate fertility preferences for DSD diagnoses contained 1,039 individuals.

This study reported that $55 \%$ of patients who thought they were unable to have biological children expressed a desire to have had fertility treatment in the past or have it in the future. In addition, $40 \%$ indicated that they would like to try new techniques for fertility treatment in the future ${ }^{53}$ 
Fertility preservation has been driven predominantly by oncofertility which is a field dedicated to preserving the fertility of patients undergoing gonadotoxic cancer treatment. As there is growing evidence of individuals with DSD wishing to retain the potential for biological fertility 2,53 , the use of fertility preservation techniques could, and should, be expanded to include this group.

It is important to address inheritance of the aforementioned conditions to any children born from potential fertility treatment. AIS is an X-linked recessive disorder that largely affects males, and females are carriers without the condition. 17-beta hydroxysteroid dehydrogenase 3 deficiency and 5 alphareductase deficiency are inherited in an autosomal recessive pattern which means both copies of the gene in each cell need to be affected in order to have the condition.

Although people who are genetically female may inherit mutations in both copies of the gene, their sexual development is not affected. The development of female sex characteristics does not require dihydrotestosterone or testosterone, so a lack of steroid 5-alpha reductase 2 or 17-beta hydroxysteroid dehydrogenase 3 activity does not cause physical changes in these individuals. Only people who have mutations in both copies of the gene and are genetically male have the characteristic signs of these conditions.

Pre-implantation genetic diagnosis (PGD) and sex selection are approved by The Human Fertilisation and Embryology Authority (HFEA) and UK Law for "conditions where a physical or mental disability illness or other medical condition is genderrelated ie; it affects only one sex or affects one sex significantly more than the other" 54. Both PGD and sex selection are widely used throughout the UK and are readily available if required by a patient. In this way, embryos created using IVF could be biopsied to screen for the condition itself or to sex select for a female in order to avoid or minimise inheritance of the genetic condition to any children.

\section{Gonadal tissue cryopreservation and in vitro maturation:}

Cryopreservation of mature sperm is routinely used for fertility preservation for men and some post-pubertal boys, but cryopreservation of post-pubertal 
testicular tissue can also be used for azoospermic patients having orchidectomy or patients too ill to produce a semen sample before starting cancer treatment. Cryopreservation of immature testicular tissue containing spermatogonial stem cells (SSCs) and spermatogonial cells is the only option that can be offered to pre-pubertal patients to date ${ }^{55-57 .}$

HFEA storage regulations allow gametes to be stored for longer than the 10-year standard period (up to 55 years) if a registered medical practitioner gives a written opinion that the individual whose gametes are being stored is likely to become prematurely infertile. Gonadal tissue must be stored in a centre that has HFEA accreditation ${ }^{54}$. This means that gonadal tissue can be cryopreserved in childhood and stored for future use well into middle or late adulthood.

Ovarian tissue cryopreservation was proposed over 50 years ago with storage and preservation of testicular tissue being available for about the last 20 years. Progress of this research has mainly focussed on ovarian cortex cryopreservation with the view to either future reimplantation of tissue or culture and production of mature oocytes by in vitro maturation (IVM) ${ }^{58}$ with the hopes of restoring fertility in those deemed at high risk of premature ovarian insufficiency (previously known as premature ovarian failure). In vitro development of follicles with IVM of oocytes isolated from cryopreserved ovarian cortex has not yet resulted in pregnancy, however, IVM from isolated immature oocytes and orthotopic autotransplantation of cryopreserved ovarian tissue has yielded pregnancies and so far, to our knowledge, 130 live births in the published literature ${ }^{59}$ with more being reported $60-63$

The successful clinical application and outcome of ovarian tissue cryopreservation is paving the way for similar research being conducted in cryopreserved pre-pubertal testicular tissue. For the purposes of this review, the focus is on in vitro maturation of spermatogonial germ cells rather than on transplanting germ cell suspensions into testes or testicular tissue reimplantation. The advantage of the former approach is to avoid the reintroduction of tissue that has increased risk of malignancy or where orchidectomy is being performed as part of female sex assignment. 
IVM of testicular germ cells, leading to in vitro-derived male haploid gametes, circumvents the risk of reintroducing the malignant cells, making this procedure potentially highly beneficial to patients with a risk of cancer. This approach is also the only way to preserve fertility in pre-pubertal boys where the testes are immature.

Promising results from animal studies and xenotransplant models have demonstrated in vitro growth and differentiation of germ cells. These studies relate to using testicular tissue taken from normal, healthy participants. Culture techniques include three-dimensional (3D) culture of testicular cells in soft agar 64 and organ culture 65,66 . The main difference between the two approaches lies in the fact that in organ culture the testicular biopsy remains intact and is layered upon an island of agar that is maintained in a liquid medium. In 3D culture, the germ cells are dissociated from their somatic cells prior to culture and they are then suspended in medium containing 35 and 50\% agar. In both systems SSCs are co-cultured with somatic cells from the same biopsy to resemble in vivo conditions and support communication between the different cellular compartments. In the mouse model, in vitro spermatogenesis has been completed successfully from the pre-meiotic stage to obtaining morphologically normal spermatozoa ${ }^{64}$ but so far offspring have only been generated with sperm derived following organ culture 65 .

Hence, on the basis of these encouraging results of spermatogonial IVM using animal models, a number of studies have investigated culture systems suitable for in vitro spermatogenesis in humans ${ }^{46,67-69}$. Most older studies describe culture systems using Vero cells (lineage of cells used for cell culture isolated from the African green monkey) or Vero cell-conditioned media ${ }^{67-69}$. Normally differentiated elongated spermatids and even mature spermatozoa have been generated from human round spermatids that were able to fertilize human oocytes and achieve normal embryonic development 67 and a live birth has been reported from IVM of primary spermatocytes ${ }^{70}$.

The addition of Vero cell-conditioned media to a mixture of different types of spermatogonial cells co-cultured with Sertoli cells, supplemented with FSH and testosterone, induced differentiation of human primary spermatocytes from 
non-obstructive azoospermic men into round spermatids at a rate of 3-7\%, and from round spermatids into normal late spermatids at a rate of $5-32 \%{ }^{68}$. Coculture of isolated primary spermatocytes with Vero cells generated chromosomally normal round spermatids 69 .

The animal origins of Vero cell culture and media is very likely to preclude their use in clinical practice. Therefore more recent studies have focused on the optimising 3D culture systems. There is a recent report of 14 lives births following injection of round spermatids into oocytes without the addition of Vero cell-conditioned media71. Another area under development is investigating differentiation of human spermatogonial cells within organoids with RT-PCR for protamine 1(PRM1) as a post meiotic marker. PRM1 expression increased 30 and 53 -fold in the first and second weeks of 3D culture respectively ${ }^{72}$. Culture of post meiotic germ cells in organoids is an exciting step forward and establishing their fertility potential will be an area to focus on future research.

For pre-pubertal boys who do not yet produce spermatozoa, freezing of immature testicular tissue to preserve spermatogonial stem cells for future use, has been suggested and is considered ethically acceptable 73, 74. Several teams have developed cryopreservation protocols for human immature testicular tissue $75-77$. Although this approach remains experimental, the capacity of human spermatogonia to survive after freezing has been demonstrated in vitro ${ }^{76}$ and the ability of these immature cells to proliferate and initiate differentiation has been observed using xenografting experiments ${ }^{78},{ }^{79}$. Meiosis and spermatogenesis also appear to resume under culture conditions, yielding normal spermatids with fertilization potential demonstrated by blastocyst formation 68 .

Encouraging results have also been obtained regarding the genetic and epigenetic stability of human SSCs during long-term culture ${ }^{80}$. Most promisingly, the first reported in vitro maturation of spermatogonial cells from pre-pubertal boys following cancer treatment in 3D methylcellulose culture system to postmeiotic sperm-like cells has recently been published ${ }^{81}$. However, similar xenotransplant models and human studies using testicular tissue from patients 
with DSD are required in order to extrapolate that their spermatogonia also have the capability to form fertile gametes.

Over the next few years, research will continue to focus on identification of the ideal microenvironment for in vitro spermatogonial cell and SSC development. The animal origins of Vero cell culture and media is very likely to preclude their use in clinical practice and therefore the emphasis is going to be on optimising 3D culture systems.

Based upon the success of fertility restoration approaches with ovarian tissue cryopreservation $^{82}$ and the promising advances in spermatogonial cell IVM, testicular tissue cryopreservation is now being offered to young boys prior to cancer treatment. There is every hope that in the next 10-20 years, various fertility restoration options will become available for today's pre-pubertal boys who were given the opportunity to bank their tissue.

Several challenges still need to be overcome before in vitro-derived sperm can be used for infertility treatment. A suitable microenvironment is essential to produce fully functional sperm cells; the epigenetic state of in vitro-derived sperm should be assessed thoroughly prior to use to ensure the production of healthy offspring. However, the ultimate standard by which in vitro spermatogenesis needs to be measured is the production of healthy and euploid offspring, which has been achieved by studies in animals 83,84 , paving the way for human gametogenesis in vitro in the future.

\section{Conclusion}

There is evidence to suggest reproductive potential in the testicular tissue removed from individuals with XY DSD in terms of the presence of germ cells. Larger confirmatory studies and studies looking into the reproductive development of these germ cells in vitro and in xenografting experiments are required. However, based on current research findings, patients without DSD who face infertility, and are unable to bank semen, are being offered testicular tissue cryopreservation as way to try and safeguard fertility potential. Therefore the same options and opportunities in terms of fertility preservation should be 
offered to DSD patients as to other patient groups.

\section{References}

1 Guercio, G., Costanzo, M., Grinspon, R.P. \& Rey, R.A. (2015) Fertility Issues in Disorders of Sex Development. Endocrinol Metab Clin North Am 44, 867-881.

2 Lee PA, N.A., Houk CP, Ahmed SF, Auchus R, Baratz A, Dalke KB, Liao LM, Lin-Su K, Looijenga 3rd LH, Mazur T. (2016) Global disorders of sex development update since 2006: perceptions, approach and care. Hormone Research in Paediatrics. 85, 158-158. 3 Tiepolo, L. \& Zuffardi, O. (1976) Localization of factors controlling spermatogenesis in the nonfluorescent portion of the human Y chromosome long arm. Hum Genet 34, 119-124.

4 Steinberger, E. (1971) Hormonal control of mammalian spermatogenesis. Physiol $\operatorname{Rev} \mathbf{5 1}, 1-22$.

5 Clermont, Y. (1966) Renewal of spermatogonia in man. Am J Anat 118, 509-524. 6 Dym, M. (1994) Spermatogonial stem cells of the testis. Proc Natl Acad Sci U S A 91, 11287-11289.

7 Griswold, M.D. (1998) The central role of Sertoli cells in spermatogenesis. Semin Cell Dev Biol 9, 411-416.

8 Hughes, I.A., Davies, J.D., Bunch, T.I., Pasterski, V., Mastroyannopoulou, K. \& MacDougall, J. (2012) Androgen insensitivity syndrome. Lancet 380, 1419-1428. 9 Mendoza, N. \& Motos, M.A. (2013) Androgen insensitivity syndrome. Gynecol Endocrinol 29, 1-5.

10 Batch JA, P.M., Hughes LA. Androgen insensitivity syndrome. Reproductive Medicine Review. 1992 Jul;1(2):131-50. (1992) Androgen insensitivity syndrome. Reproductive Medicine Review 1, 131-150.

11 Hughes, I.A., Houk, C., Ahmed, S.F., Lee, P.A. \& Lawson Wilkins Pediatric Endocrine Society/European Society for Paediatric Endocrinology Consensus, G. (2006) Consensus statement on management of intersex disorders. J Pediatr Urol 2, 148-162.

12 Cools, M., Drop, S.L., Wolffenbuttel, K.P., Oosterhuis, J.W. \& Looijenga, L.H. (2006) Germ cell tumors in the intersex gonad: old paths, new directions, moving frontiers. Endocr Rev 27, 468-484.

13 Cools M, W.K., Hersmus R, Mendonca BB, Kaprová J, Drop SL, Stoop H, Gillis AJ, Oosterhuis JW, Costa EM, Domenice S. . (2017) Malignant testicular germ cell tumors in postpubertal individuals with androgen insensitivity: prevalence, pathology and relevance of single nucleotide polymorphism-based susceptibility profiling

.Hum Reprod 7, 2561-2573.

14 Rutgers, J.L. \& Scully, R.E. (1991) The androgen insensitivity syndrome (testicular feminization): a clinicopathologic study of 43 cases. Int J Gynecol Pathol 10, 126-144.

15 Deans, R., Creighton, S.M., Liao, L.M. \& Conway, G.S. (2012) Timing of gonadectomy in adult women with complete androgen insensitivity syndrome (CAIS): patient preferences and clinical evidence. Clin Endocrinol (Oxf) 76, 894-898.

16 Rajpert-De Meyts E, M.K., Okamoto K, Jewett MA, Bokemeyer C. (2016)

Testicular germ cell tumours. The Lancet. 387, 1762-1774.

17 Nakhal, R.S., Hall-Craggs, M., Freeman, A., Kirkham, A., Conway, G.S., Arora, R., Woodhouse, C.R., Wood, D.N. \& Creighton, S.M. (2013) Evaluation of retained testes in 
adolescent girls and women with complete androgen insensitivity syndrome. Radiology 268, 153-160.

18 Jaaskelainen, J. (2012) Molecular biology of androgen insensitivity. Mol Cell Endocrinol 352, 4-12.

19 Cools M, V.A.K., Kersemaekers AM, Boter M, Drop SL, Wolffenbuttel KP, Steyerberg EW, Oosterhuis JW, Looijenga LH. (2005) Morphological and immunohistochemical differences between gonadal maturation delay and early germ cell neoplasia in patients with undervirilization syndromes. . The Journal of Clinical Endocrinology \& Metabolism. 90, 5295-5303.

20 Hannema, S.E., Scott, I.S., Rajpert-De Meyts, E., Skakkebaek, N.E., Coleman, N. \& Hughes, I.A. (2006) Testicular development in the complete androgen insensitivity syndrome. J Pathol 208, 518-527.

21 Kaprova-Pleskacova, J., Stoop, H., Bruggenwirth, H., Cools, M., Wolffenbuttel, K.P., Drop, S.L., Snajderova, M., Lebl, J., Oosterhuis, J.W. \& Looijenga, L.H. (2014) Complete androgen insensitivity syndrome: factors influencing gonadal histology including germ cell pathology. Mod Pathol 27, 721-730.

22 Kolesinska, Z., Ahmed, S.F., Niedziela, M., Bryce, J., Molinska-Glura, M., Rodie, M., Jiang, J., Sinnott, R.O., Hughes, I.A., Darendeliler, F., Hiort, O., van der Zwan, Y., Cools, M., Guran, T., Holterhus, P.M., Bertelloni, S., Lisa, L., Arlt, W., Krone, N., Ellaithi, M., Balsamo, A., Mazen, I., Nordenstrom, A., Lachlan, K., Alkhawari, M., Chatelain, P. \& Weintrob, N. (2014) Changes over time in sex assignment for disorders of sex development. Pediatrics 134, e710-715.

23 Lucas-Herald, A., Bertelloni, S., Juul, A., Bryce, J., Jiang, J., Rodie, M., Sinnott, R., Boroujerdi, M., Lindhardt Johansen, M., Hiort, O., Holterhus, P.M., Cools, M., GuaragnaFilho, G., Guerra-Junior, G., Weintrob, N., Hannema, S., Drop, S., Guran, T., Darendeliler, F., Nordenstrom, A., Hughes, I.A., Acerini, C., Tadokoro-Cuccaro, R. \& Ahmed, S.F. (2016) The Long-Term Outcome of Boys With Partial Androgen Insensitivity Syndrome and a Mutation in the Androgen Receptor Gene. J Clin Endocrinol Metab 101, 3959-3967.

24 Imperato-McGinley, J., Guerrero, L., Gautier, T. \& Peterson, R.E. (1974) Steroid 5alpha-reductase deficiency in man: an inherited form of male pseudohermaphroditism. Science 186, 1213-1215.

25 Walsh, P.C., Madden, J.D., Harrod, M.J., Goldstein, J.L., MacDonald, P.C. \& Wilson, J.D. (1974) Familial incomplete male pseudohermaphroditism, type 2. Decreased dihydrotestosterone formation in pseudovaginal perineoscrotal hypospadias. $N \mathrm{Engl} \mathrm{J}$ Med 291, 944-949.

26 Imperato-McGinley, J. \& Peterson, R.E. (1976) Male pseudohermaphroditism: the complexities of male phenotypic development. Am J Med 61, 251-272.

27 Berra, M., Williams, E.L., Muroni, B., Creighton, S.M., Honour, J.W., Rumsby, G. \& Conway, G.S. (2011) Recognition of 5alpha-reductase-2 deficiency in an adult female 46XY DSD clinic. Eur J Endocrinol 164, 1019-1025.

28 Mendonca, B.B., Batista, M.C., Arnhold, I.J., Nicolau, W., Madureira, G., Lando, V.S., Kohek, M.B., Carvalho, D.G. \& Bloise, W. (1987) Male pseudohermaphroditism due to 5 alpha reductase deficiency associated with gynecomastia. Rev Hosp Clin Fac Med Sao Paulo 42, 66-68.

29 Sultan, C., Paris, F., Terouanne, B., Balaguer, P., Georget, V., Poujol, N., Jeandel, C., Lumbroso, S. \& Nicolas, J.C. (2001) Disorders linked to insufficient androgen action in male children. Hum Reprod Update 7, 314-322.

30 Cohen-Kettenis, P.T. (2005) Gender change in 46,XY persons with 5alphareductase- 2 deficiency and 17beta-hydroxysteroid dehydrogenase-3 deficiency. Arch Sex Behav 34, 399-410.

31 Hadziselimovic F, D.N.S.-- (2008) Differences in testicular development between $5 \alpha$-reductase 2 deficiency and isolated bilateral cryptorchidism. J Urol 180, 1116-1120. 
32 Okon E, L.N., Rösler A, Yorkoni S, Segal S, Kohn G, Schenker JG. (1980) Male pseudohermaphroditism due to 5 alpha-reductase deficiency. Ultrastructure of the gonads. Archives of pathology \& laboratory medicine. 104, 363-367.

33 Cai, L.Q., Fratianni, C.M., Gautier, T. \& Imperato-McGinley, J. (1994)

Dihydrotestosterone regulation of semen in male pseudohermaphrodites with 5 alphareductase-2 deficiency. J Clin Endocrinol Metab 79, 409-414.

34 Kolasa, A., Marchlewicz, M., Wenda-Rozewicka, L. \& Wiszniewska, B. (2004) Morphology of the testis and the epididymis in rats with dihydrotestosterone (DHT) deficiency. Rocz Akad Med Bialymst 49 Suppl 1, 117-119.

35 Katz, M.D., Kligman, I., Cai, L.Q., Zhu, Y.S., Fratianni, C.M., Zervoudakis, I., Rosenwaks, Z. \& Imperato-McGinley, J. (1997) Paternity by intrauterine insemination with sperm from a man with 5alpha-reductase-2 deficiency. $N$ Engl J Med 336, 994-997. 36 Kang, H.J., Imperato-McGinley, J., Zhu, Y.S. \& Rosenwaks, Z. (2014) The effect of 5alpha-reductase-2 deficiency on human fertility. Fertil Steril 101, 310-316.

37 Phelan N, W.E., Cardamone S, Lee M, Creighton SM, Rumsby G, Conway GS. . . 2015 Jun 1;172(6):745-51. (2015) Screening for mutations in 17ß-hydroxysteroid dehydrogenase and androgen receptor in women presenting with partially virilised 46, $\mathrm{XY}$ disorders of sex development. European journal of endocrinology 1, 745-751. 38 Rösler A, B.A., Labrie FE. Mechanisms of androgen production in male pseudohermaphroditism due to 17 beta-hydroxysteroid dehydrogenase deficiency. 1992 Sep 1;75(3):773-8. (1992) Mechanisms of androgen production in male pseudohermaphroditism due to 17 beta-hydroxysteroid dehydrogenase deficiency. The Journal of Clinical Endocrinology \& Metabolism. 75, 773-778.

39 Farkas A, R.A.T.y.e.w.m.g.i.m.p.d.t.ß.-h.d.d.F. (1993) Ten years experience with masculinizing genitoplasty in male pseudohermaphroditism due to $17 \beta$-hydroxysteroid dehydrogenase deficiency. European Journal of Pediatrics. 152, S88-90.

40 Dumic, M., Plavsic, V., Fattorini, I. \& Ille, J. (1985) Absent spermatogenesis despite early bilateral orchidopexy in 17-ketoreductase deficiency. Horm Res 22, 100106.

41 Auchus, R.J. \& Miller, W.L. (2012) Defects in androgen biosynthesis causing 46,XY disorders of sexual development. Semin Reprod Med 30, 417-426.

42 Mains, L.M., Vakili, B., Lacassie, Y., Andersson, S., Lindqvist, A. \& Rock, J.A. (2008) 17 beta-hydroxysteroid dehydrogenase 3 deficiency in a male pseudohermaphrodite. Fertil Steril 89, 228 e213-227.

43 Balducci R, T.V., Wright F, Bozzolan F, Di Piero G, Maroder M, Panei P, Sciarra F, Boscherini B. (1985) Familial male pseudohermaphroditism with gynaecomastia due to $17 \beta$ - hydroxysteroid dehydrogenase deficiency. A report of 3 cases. Clinical endocrinology. 23, 439-444.

44 Longo FJ, C.S., Givens JR . 1975 Aug 1;64(2):145-54. (1975) Ultrastructural Analysis of the Testes in Male Pseudohermaphrodism Due to Deficiency of 17Ketosteroid Reductase. American journal of clinical pathology 64, 145-154.

45 Faienza, M.F., Giordani, L., Delvecchio, M. \& Cavallo, L. (2008) Clinical, endocrine, and molecular findings in 17beta-hydroxysteroid dehydrogenase type 3 deficiency. $J$ Endocrinol Invest 31, 85-91.

46 Lee JH, G.M., Choi KW, Hong JY, Lee YB, Park DW, Lee SJ, Min CK. (2007) In vitro differentiation of germ cells from nonobstructive azoospermic patients using threedimensional culture in a collagen gel matrix. Fertility and sterility. 87, 824-833.

47 Houk CP, H.I., Ahmed SF, Lee PA. Summary of consensus statement on intersex disorders and their management. 2006 Aug 1;118(2):753-7. (2006) Summary of consensus statement on intersex disorders and their management. Pediatrics. 118, 753757. 
48 Hadziselimovic F, H.N., Demougin P, Oakeley EJ. Testicular gene expression in cryptorchid boys at risk of azoospermia. 2011;5(2):49-59. (2011) Testicular gene expression in cryptorchid boys at risk of azoospermia. Sexual Development. 5, 49-59. 49 Hadziselimovic, F., Gegenschatz-Schmid, K., Verkauskas, G., Docampo-Garcia, M.J., Demougin, P., Bilius, V., Malcius, D., Dasevicius, D. \& Stadtler, M.B. (2016) Gene Expression Changes Underlying Idiopathic Central Hypogonadism in Cryptorchidism with Defective Mini-Puberty. Sex Dev 10, 136-146.

50 Regadera, J., Martinez-Garcia, F., Paniagua, R. \& Nistal, M. (1999) Androgen insensitivity syndrome: an immunohistochemical, ultrastructural, and morphometric study. Arch Pathol Lab Med 123, 225-234.

51 Ribeiro Scolfaro, M., Aparecida Cardinalli, I., Gabas Stuchi-Perez, E., Palandi de Mello, M., de Godoy Assumpcao, J., Matias Baptista, M.T., Bustorff Silva, J.M., Trevas Maciel-Guerra, A. \& Guerra, G., Jr. (2001) Morphometry and histology of gonads from 13 children with dysgenetic male pseudohermaphroditism. Arch Pathol Lab Med 125, 652656.

52 Finlayson, C., Fritsch, M.K., Johnson, E.K., Rosoklija, I., Gosiengfiao, Y., Yerkes, E., Madonna, M.B., Woodruff, T.K. \& Cheng, E. (2017) Presence of Germ Cells in Disorders of Sex Development: Implications for Fertility Potential and Preservation. J Urol 197, 937 943.

53 Slowikowska-Hilczer, J., Hirschberg, A.L., Claahsen-van der Grinten, H., Reisch, N., Bouvattier, C., Thyen, U., Cohen Kettenis, P., Roehle, R., Kohler, B., Nordenstrom, A. \& dsd, L.G. (2017) Fertility outcome and information on fertility issues in individuals with different forms of disorders of sex development: findings from the dsd-LIFE study. Fertil Steril 108, 822-831.

54 http://www.hfea.gov.uk (2017) Code of practice-the HFEA.

55 Wyns, C., Curaba, M., Vanabelle, B., Van Langendonckt, A. \& Donnez, J. (2010)

Options for fertility preservation in prepubertal boys. Hum Reprod Update 16, 312-328.

56 Wyns C, C.M., Petit S, Vanabelle B, Laurent P, Wese JF, Donnez J. 2011 Jan

11;26(4):737-47. (2011) Management of fertility preservation in prepubertal patients: 5 years' experience at the Catholic University of Louvain. Human reproduction. 26, 737747.

57 Picton, H.M., Wyns, C., Anderson, R.A., Goossens, E., Jahnukainen, K., Kliesch, S., Mitchell, R.T., Pennings, G., Rives, N., Tournaye, H., van Pelt, A.M., Eichenlaub-Ritter, U., Schlatt, S. \& Diseases, E.T.F.O.F.P.I.S. (2015) A European perspective on testicular tissue cryopreservation for fertility preservation in prepubertal and adolescent boys. Hum Reprod 30, 2463-2475.

58 Donnez, J. \& Bassil, S. (1998) Indications for cryopreservation of ovarian tissue. Hum Reprod Update 4, 248-259.

59 Gellert, S.E., Pors, S.E., Kristensen, S.G., Bay-Bjorn, A.M., Ernst, E. \& Yding Andersen, C. (2018) Transplantation of frozen-thawed ovarian tissue: an update on worldwide activity published in peer-reviewed papers and on the Danish cohort. J Assist Reprod Genet 35, 561-570.

60 Jensen AK, M.K., Fedder J, Ernst E, Humaidan P, Andersen CY. . 2017 Mar 1;34(3):325-36. (2017) 86 successful births and 9 ongoing pregnancies worldwide in women transplanted with frozen-thawed ovarian tissue: focus on birth and perinatal outcome in 40 of these children. Journal of assisted reproduction and genetics $\mathbf{3 4}, 325-$ 336.

61 Donnez, J., Dolmans, M.M., Pellicer, A., Diaz-Garcia, C., Sanchez Serrano, M., Schmidt, K.T., Ernst, E., Luyckx, V. \& Andersen, C.Y. (2013) Restoration of ovarian activity and pregnancy after transplantation of cryopreserved ovarian tissue: a review of 60 cases of reimplantation. Fertil Steril 99, 1503-1513.

62 Meirow, D., Ra'anani, H. \& Biderman, H. (2014) Ovarian tissue cryopreservation and transplantation: a realistic, effective technology for fertility preservation. Methods Mol Biol 1154, 455-473. 
63 Demeestere, I., Simon, P., Dedeken, L., Moffa, F., Tsepelidis, S., Brachet, C., Delbaere, A., Devreker, F. \& Ferster, A. (2015) Live birth after autograft of ovarian tissue cryopreserved during childhood. Hum Reprod 30, 2107-2109.

64 Stukenborg, J.B., Wistuba, J., Luetjens, C.M., Elhija, M.A., Huleihel, M., Lunenfeld, E., Gromoll, J., Nieschlag, E. \& Schlatt, S. (2008) Coculture of spermatogonia with somatic cells in a novel three-dimensional soft-agar-culture-system. J Androl 29, 312-329.

65 Sato, T., Katagiri, K., Yokonishi, T., Kubota, Y., Inoue, K., Ogonuki, N., Matoba, S., Ogura, A. \& Ogawa, T. (2011) In vitro production of fertile sperm from murine spermatogonial stem cell lines. Nat Commun 2, 472.

66 Gholami K, P.G., Koruji M, Ashouri S, Abbasi M. Stem cell research \& therapy. (2018) Organ culture of seminiferous tubules using a modified soft agar culture system. Stem cell research \& therapy $9,249$.

67 Cremades N, S.M., Bernabeu R, Barros A. 2001 Sep 1;16(9):1938-44. (2001) Developmental potential of elongating and elongated spermatids obtained after in-vitro maturation of isolated round spermatids. Human reproduction. 16, 1938-1944.

68 Sousa, M., Cremades, N., Alves, C., Silva, J. \& Barros, A. (2002) Developmental potential of human spermatogenic cells co-cultured with Sertoli cells. Hum Reprod 17, 161-172.

69 Tanaka A, N.M., Awata S, Mawatari Y, Tanaka I, Kusunoki H. . 2003 Mar 1;79:795-801. (2003) Completion of meiosis in human primary spermatocytes through in vitro coculture with Vero cells. Fertility and sterility. 1, 795-801.

70 Tesarik, J., Bahceci, M., Ozcan, C., Greco, E. \& Mendoza, C. (1999) Restoration of fertility by in-vitro spermatogenesis. Lancet 353, 555-556.

71 Tanaka A, N.M., Takemoto Y, Tanaka I, Kusunoki H, Watanabe S, Kuroda K, Takeda S, Ito M, Yanagimachi R. 2015 Nov 24;112(47):14629-34. (2015) Fourteen babies born after round spermatid injection into human oocytes. Proceedings of the National Academy of Sciences. 112, 4629-4634.

72 McAbee KE, Z.N., Atala A, Sadri-Ardekani H, Bishop C. IN VITRO

DIFFERENTIATION OF HUMAN SPERMATOGONIAL STEM CELLS IN A THREE

DIMENSIONAL (3D) TESTICULAR ORGANOID SYSTEM. The Journal of Urology. 1, 543.

73 Bahadur, G., Chatterjee, R. \& Ralph, D. (2000) Testicular tissue cryopreservation in boys. Ethical and legal issues: case report. Hum Reprod 15, 1416-1420.

74 Tournaye, H., Goossens, E., Verheyen, G., Frederickx, V., De Block, G., Devroey, P. \& Van Steirteghem, A. (2004) Preserving the reproductive potential of men and boys with cancer: current concepts and future prospects. Hum Reprod Update 10, 525-532. 75 Kvist, K., Thorup, J., Byskov, A.G., Hoyer, P.E., Mollgard, K. \& Yding Andersen, C. (2006) Cryopreservation of intact testicular tissue from boys with cryptorchidism. Hum Reprod 21, 484-491.

76 Keros, V., Hultenby, K., Borgstrom, B., Fridstrom, M., Jahnukainen, K. \& Hovatta, 0. (2007) Methods of cryopreservation of testicular tissue with viable spermatogonia in pre-pubertal boys undergoing gonadotoxic cancer treatment. Hum Reprod 22, 13841395.

77 Wyns, C., Curaba, M., Martinez-Madrid, B., Van Langendonckt, A., FrancoisXavier, W. \& Donnez, J. (2007) Spermatogonial survival after cryopreservation and short-term orthotopic immature human cryptorchid testicular tissue grafting to immunodeficient mice. Hum Reprod 22, 1603-1611.

78 Wyns, C., Van Langendonckt, A., Wese, F.X., Donnez, J. \& Curaba, M. (2008) Longterm spermatogonial survival in cryopreserved and xenografted immature human testicular tissue. Hum Reprod 23, 2402-2414.

79 Sadri-Ardekani, H., Mizrak, S.C., van Daalen, S.K., Korver, C.M., Roepers-Gajadien, H.L., Koruji, M., Hovingh, S., de Reijke, T.M., de la Rosette, J.J., van der Veen, F., de Rooij, D.G., Repping, S. \& van Pelt, A.M. (2009) Propagation of human spermatogonial stem cells in vitro. JAMA 302, 2127-2134. 
80 Nickkholgh, B., Mizrak, S.C., van Daalen, S.K., Korver, C.M., Sadri-Ardekani, H., Repping, S. \& van Pelt, A.M. (2014) Genetic and epigenetic stability of human spermatogonial stem cells during long-term culture. Fertil Steril 102, 1700-1707 e1701. 81 Abofoul-Azab, M., AbuMadighem, A., Lunenfeld, E., Kapelushnik, J., Shi, Q., Pinkas, H. \& Huleihel, M. (2018) Development of Postmeiotic Cells In Vitro from Spermatogonial Cells of Prepubertal Cancer Patients. Stem Cells Dev 27, 1007-1020.

82 Donnez, J., Dolmans, M.M., Demylle, D., Jadoul, P., Pirard, C., Squifflet, J., MartinezMadrid, B. \& van Langendonckt, A. (2004) Livebirth after orthotopic transplantation of cryopreserved ovarian tissue. Lancet 364, 1405-1410.

83 Zhou, Q., Wang, M., Yuan, Y., Wang, X., Fu, R., Wan, H., Xie, M., Liu, M., Guo, X., Zheng, Y., Feng, G., Shi, Q., Zhao, X.Y., Sha, J. \& Zhou, Q. (2016) Complete Meiosis from Embryonic Stem Cell-Derived Germ Cells In Vitro. Cell Stem Cell 18, 330-340.

84 Hayashi, K., Ogushi, S., Kurimoto, K., Shimamoto, S., Ohta, H. \& Saitou, M. (2012) Offspring from oocytes derived from in vitro primordial germ cell-like cells in mice. Science 338, 971-975. 